\title{
The real effective exchange rate misalignment: Application of Behavioral Equilibrium Exchange Rate BEER to Algeria 1980-2009
}

\author{
Abbes Hiri \\ School of Finance, Shanghai University of Finance \& Economics, Shanghai, China \\ Email address: \\ hiri91@hotmail.com
}

\section{To cite this article:}

Abbes Hiri. The Real Effective Exchange Rate Misalignment: Application of Behavioral Equilibrium Exchange Rate BEER to Algeria 19802009. International Journal of Economics, Finance and Management Sciences. Vol. 2, No. 5, 2014, pp. 277-284.

doi: 10.11648/j.ijefm.20140205.12

\begin{abstract}
In this research paper, I determine equilibrium real exchange rate of Algerian Dinar (DZD) in order to see the influence of fundamental factors toward Algerian Dinar exchange rate, and to understand the appropriate level or sustainability long term trend. Furthermore, I figure out the misalignment for real exchange rate of Algerian dinar. The period of this research paper covers the post crisis era from 1980 to 2009 (quarterly). Using co-integrating regression, I find that variables OIL, GC, LQ, TR, NCF, CF, OPEN and TT have significant influence to real exchange rate in the long run. Misalignment episode gives us seven patterns of situation during this period which are undervaluation during the periods: 1981Q1-1984Q2, 1988Q11992Q4, 1994Q2-1996Q4, and 2002Q3-2008Q2; and overvaluation during the periods: 1984Q3-1987Q4, 1993Q1-1994Q1, and 1997Q1-2002Q2.
\end{abstract}

Keywords: Real Effective Exchange Rate, BEER, Algeria, Oil Price, Oil Exporting Country

\section{Introduction}

Real effective exchange rate, REER hence forth, is a key macroeconomic relative price, which plays an important role in the board allocation of resources in production and spending behavior in the economy. REER is considered as a measures of competitiveness and one of the affective of export sector (Caballero and Corbo, 1989).Since the early seventieth, the exchange rate of the Algerian Dinars has been pegged to the basket of currencies in which the US dollars was assigned a relatively large weight due to its importance in the oil exports receipts and debt-service payments, with adjustments taking place from time to time. After 1980 the DZD started to lose in its value against the US dollar cause of the latter was getting stronger during the period of 1980-1985.

After the oil shock in 1986, the DZD didn't get back its value until the end of 1991, after the citizen war begging which affected the whole economics in Algeria. Dissimilarly, the DZD depreciated in the next period, and then kept increasing again during the rest of the period.

In order to estimate the DZD's real effective exchange rate misalignment and find out the macroeconomic fundamentals which affect it, we use the Behavioral Equilibrium Exchange Rate Approach to determine the DZD's exchange rate misalignment under this query: What is the equilibrium real effective exchange rate level of DZD? I have chosen a quarterly data from 1980 to 2009 .

\section{Literature Review and Theoretical Framework}

According to some researchers, for instance, Serven and Solimano (1991), Ghura and Grennes (1993) and Yotopoulos (1994) have found that the level of the real exchange rate (RER) relative to equilibrium RER and its stability has a robust impact on exports and private investment. Baffes, Elbadawi, and O'Connell, showed an overvaluation of actual exchange rate of Cote D'Ivoire by $34 \%$ on average, using a single equation time series over 7 years data starting from 1987. However, Maesofernandez, Osbat and Schnatz (2001), they used couple of fundamental variables: net foreign assets, 
productivity, relatives total consumption differentials, real oil price, interest rate differentials, and relative fiscal stance. After running a BEER/PEER model(using quarterly data from 1975 till 1998, they have found that there is an undervaluation of the EURO exchange rate in 2000. In 2005, Dufrenot and Yehoue explained that the exchange rate dynamics are likely to be expressed by fundamentals such as trade openness, terms of trade, and productivity in low income countries than middle income countries.

Some economists have used the BEER model to estimate the behavioral equilibrium exchange rate. This approach emphasizes variables that affect the relative prices of traded to non-traded goods at home and in foreign countries, such as differing trends in productivity in traded goods sectors and asymmetric terms-of-trade shocks.

\section{Exchange Rate Estimation Method (BEER)}

Different Scientifics use different ways to find out the equilibrium exchange rate of a certain country. The Behavioral Equilibrium Exchange Rate (BEER) is one of those methods.

$R E E R_{t}=c+\beta_{1} * O I L_{t}+\beta_{2} * G C_{t}+\beta_{3} * L Q_{t}+\beta_{4} * T R_{t}+\beta_{5}$

Where: REER is: Real effective exchange rate, OIL is: Oil price, GC is: Government consumption, LQ is: Liquidity, TR is: Total reserve include gold, NCF is: Net capital flows, CF is: Capital flows, OPEN is: Trade openness, TT is: Terms of trade.

Therefore, based on Edwards $(1989,1992)$ and El-badawi (1994, 1997, 1999) studies, I estimate single equation REER model for Algeria. At first, I have to make sure that every variable should be integrated with same order. We test all variables with unit root to determine whether they are stationary. The Augmented Dickey-Fuller (ADF) is used to check the stationary of variables for the whole period. After checking the stationary of the time series variables, I use Johansen (1988) and Johansen and Juselius (1990) cointegration analysis to do the empirical estimation of cointegrated regression.

\section{Data Source and Definition}

The basic underlying model used in this paper is the behavioral exchange rate (BEER) model. The appeal of the model lies in the fact that the equilibrium exchange rate is determined by appropriate set of explanatory variables. Moreover the movement of REER is assumed to be good proxy for the evolution of the price competitiveness of an economy. It's true that the basic structure of real exchange rate economics is well known, but causality path between the exchange rate and other fundamentals can be difficult. In this section I show the variables definitions which are suspected to be sourced of exchange rate fluctuations: oil price (OIL), Government consumption (GC), liquidity ratio (LQ), Total
Generally, The Beer approach is a way of exploiting theoretical exchange rate model in order to get a measure of the equilibrium exchange rate and consequently, exchange rate misalignment. BEER approach focuses on the exchange rate dynamic behavior, including short run deviations and movements and considering boarder macroeconomic conditions into account. As the BEER approach is more applicable for a developing countries (large and complex model are often not feasible), I use this model to measure out the equilibrium exchange rate in our research.

\section{The Econometric Methodology}

This chapter mainly traces empirically the estimation of the equilibrium real exchange rate for Algeria from the beginning of 1980's until the end of 2009, using a quarterly data in order to understand the misalignment episode in the Real Effective exchange rate (REER). As I above mentioned, I adopt the BEER approach in our research and specify the REER as the function of vector of macroeconomic fundamental variables. The theoretical formula defining my model is:

$\beta_{5} * N C F_{t}+\beta_{6} * C F_{t}+\beta_{7} * O P E N_{t}+\beta_{8} * T T_{t}+R E S I D U A L_{t}$

reserve including gold (TR), net capital flows (NCF), capital flows (CF), trade openness (OPEN) and terms of trade (TT). The variables are used in form of quarterly data from the first quarter of 1980 till the fourth quarter of 2009 and we expect the sign of each variable to be as follow ${ }^{1}$ :

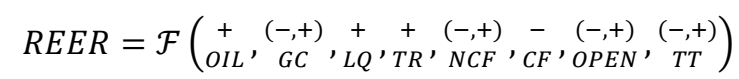

\subsection{Reel Effective Exchange Rate (REER)}

Here I am using real effective exchange rate instead of real exchange rate, which is measured as the following form:

$$
R E E R=\prod_{i=1}^{n}\left[\frac{B^{D Z D} \cdot C P^{D Z D}}{B^{i} \cdot C P^{i}}\right]^{w}
$$

$B^{D Z D}$ and $B^{i}$ are the bilateral exchange rate of DZD and Algeria's trade partner $i$ 's currency respectively. $C P^{D Z D}, B^{D Z D}$, and $\mathrm{w}$ are the consumer price index for Algeria, consumer price index for country $I$ and the trade weight (percentage) of Algeria's trader partner country $i$, respectively.

\subsection{Oil Price (OIL)}

Since Algeria's exports mainly rely on its oil exports (Hydrocarbons still topped the list of Algerian exports at $97.06 \%$ ), I use the OIL variable as an additional indicator of capital flows fluctuations. Because an increase in the oil prices, will lead to increase in the value of exports which

\footnotetext{
1 - Zulfiqar Hyder and Adil Mahboub, "Equilibrium real effective exchange rate and exchange rate misalignment in Pakistan”, (2005) ,SBP electronic board
} 
automatically will increases the capital in-flows. ${ }^{2}$

\subsection{Government Consumption (GC)}

If consumption is biased in favor of the non-tradable goods, an increase in GC will lead to an increase in the prices of non-tradable goods and an appreciation of the REER $^{3}$.

Government Consumption (GC) = Government Expenditure/GDP

All GC data is gathered from World Bank database website. $^{4}$

\subsection{Liquidity Rate (LQ)}

The Liquidity (LQ) is the Money and quasi money (M2) as percentage of Gross domestic product (GDP). An increase in the liquidity ratio (LQ) will affect an increase in prices and an appreciation of REER (increase in the value of REER).

LQ is calculated as follow:

$$
\mathrm{LQ}=\mathrm{M} 2 / \mathrm{GDP}
$$

All LQ data is gathered from World Bank database website. $^{5}$

\subsection{Total Reserve Including Gold (TR)}

Total reserve including gold (TR) is measured as the total reserve including the gold over the gross domestic product. This ratio helps us to capture the effect of reserve of exchange rate, thus the magnitude of government interventions determine the sign of total reserve including gold.

$$
\mathrm{TR}=\text { TOTAL RESERVE INCLUDE GOLD } / \text { GDP }^{6}
$$

TR data is gathered from World Bank database website. ${ }^{7}$

\subsection{Net Capital Flows (NCF)}

The net capital flows is measured as the value of the balance of goods and services minus the change in gross international reserves including the gold as a percentage of gross domestic product. The sign of NCF depends on the government intervention. If NCF is significant this mean there is not government intervention and vice versa.

$$
N C F=\left[-\left(\frac{\text { Exports-Imports }}{G D P}\right)\right]-\left(\frac{\Delta \text { Reserve }}{G D P}\right)^{8}
$$

2 - See Bassem Kamar, "The approcriate monetary policy coordination for the GCC monetary union”, (2006), International university of Nice-Sophia Antipolis

3 - See Bassem Kamar, "Defacto exchange rate policies in the MENA region: toward deeper co-operation", (2004), International university of Monaco.

4 - http://data.worldbank.org

5 - http://data.worldbank.org

${ }^{6}$ - See Bassem Kamar, "Defacto exchange rate policies in the mena region: toward deeper coorperation", (2004), International university of Monaco

7 - http://data.worldbank.org, and calculated by author.

8 - See Bassem Kamar, "Defacto exchange rate policies in the mena region: toward deeper coorperation", (2004), International university of Monaco
All NCF data is gathered from World Bank database website. ${ }^{9}$

\subsection{Capital Flows (CF)}

We also compute and test alternatively a measure of capital flows, called $\mathrm{CF}$, which represents the net trade to GDP ratio, and the net capital flows (NCF), measured as follow:

$$
\mathrm{CF}=[-((\text { exports }- \text { imports }) / \text { GDP })]
$$

All CF data is gathered from World Bank database website. $^{10}$

\subsection{Degree of Openness (OPEN)}

The degree of openness is a ratio of trade to gross domestic product GDP, which measures the degree of the country's trade openness we use the variable OPEN (total trade as percentage of GDP). The impact of the degree of openness on REER cannot be signed a priori because degree of openness is theoretically ambiguous.

$$
\mathrm{OPEN}=(\text { exports }+ \text { imports }) / \mathrm{GDP}^{11}
$$

All CF data is calculated from data gathered from World Bank database website. ${ }^{12}$

\subsection{Terms of Trade (TT)}

Theoretically, the influence of terms of trade on the REER cannot be signed a priori, as this depends on whether income or substitution effects dominate. The former leads to real currency appreciation (increase in REER) while the latter to real currency depreciation (decrease in REER). Baffes, Elbadawi and O'Connell (1997) developed a measure of terms of trade and trade policy as the ratio of export price index to import price index.

$$
\mathrm{TT}=\text { Export prices } / \text { Import } \text { prices }^{13}
$$

All CF data is measured from data gathered from World Bank database website. ${ }^{14}$

\section{Empirical Results}

\subsection{Stationary Analysis}

First, I have checked the time series properties by testing the stationary of the fundamental variables. A unit root test has been undertaken using the augmented Dickey-Fuller (ADF) criterion. The results presented in the Table 1.

\footnotetext{
9 - http://data.worldbank.org, and calculated by author.

10 - http://data.worldbank.org, and calculated by author.

11 - See Bassem Kamar, "The appreciate monetary policy coordination for the GCC monetary union", (2006), International university of Nice-Sophia Antipolis.

12 - http://data.worldbank.org, and calculated by author.

13 -Shehu Usman Rano, Aliyu, " Real exchange rate misalignment: an application of behavioral equilibrium exchange rate to Nigeria", (2008), Munich Personal RePEc archive.

14 - http://data.worldbank.org, and calculated by author.
} 
Table 1. ADF Unit Root Test at level\#

\begin{tabular}{lllll}
\hline \multicolumn{2}{l}{ unit root test ADF TEST } & & \\
\hline series & Intercept & intercept\&trend & None & Conclusion (intercept) \\
\hline REER & -0.69 & -1.38 & -1.42 & Series Non Stationary \\
OIL & -0.54 & 0.21 & 0.34 & Series Non Stationary \\
GC & -2.08 & -3.28 & -0.35 & Series Non Stationary \\
LQ & -1.36 & -0.96 & -0.96 & Series Non Stationary \\
TR & -1.42 & -2.74 & -0.7 & Series Non Stationary \\
NCF & -1.43 & -2.75 & -2.75 & Series Non Stationary \\
CF & -2.2 & -2.2 & $2.21 * *$ & Series stationary \\
OPEN & -0.27 & -2.4 & 0.66 & Series Non Stationary \\
TT & -2.38 & -2.24 & -1.11 & Series Non Stationary \\
\hline
\end{tabular}

\# Figures in parenthesis are optimal lags based on SIC criteria

$*, * *$ and $* * *$ reflect the significance level at $1 \%, 5 \%$ and $10 \%$ respectively.
I used Schwartz Info criterion (SIC) to determine the optimal length of suitable lags for ADF test. As presented in Table 1, all the fundamentals variables are appeared to be non-stationary in the level form, except variable (CF), which is significantly stationary in none form. So, the null hypothesis of the unit root in the level series cannot be rejected for all variables, which become stationary at first difference (see the Table 2). Except the CF, All the variables are integrated of the same order i.e. I(1), which fulfills the criteria for estimating any long run relations. So I drop the variable $\mathrm{CF}$ from the equation 3-1 to become:

$$
R E E R=\mathcal{L}(O I L, G C, L Q . T R, N C F, O P E N, T T)
$$

$$
R E E R_{t}=c+\beta_{1} * O I L_{t}+\beta_{2} * G C_{t}+\beta_{3} * L Q_{t}+\beta_{4} * T R_{t}+\beta_{5} * N C F_{t}+\beta_{7} * O P E N_{t}+\beta_{8} * T T_{t}+R_{E S I D U A L_{t}}
$$

\begin{tabular}{|c|c|c|c|c|}
\hline \multicolumn{5}{|c|}{ unit root test ADF TEST } \\
\hline series & Intercept & Intercept \& trend & None & Conclusion \\
\hline DREER & $-8.444 *$ & $-8.408 *$ & $-8.333 *$ & Series Stationary I(1) \\
\hline DOIL & $-3.127 * *$ & $-7.709 *$ & $-3.074 *$ & Series Stationary I(1) \\
\hline DGC & $-3.598^{*}$ & $-3.609 * *$ & $-3.614 *$ & Series Stationary I(1) \\
\hline DLQ & $-2.580 * * *$ & -2.722 & $-2.524 * *$ & Series Stationary I(1) \\
\hline DTR & -3.827 & $-3.889 * *$ & $-3.844^{*}$ & Series Stationary I(1) \\
\hline DNCF & $-3.762 *$ & $-3.857 * *$ & $-3.771 *$ & Series Stationary I(1) \\
\hline DCF & -1.231 & -0.997 & -1.327 & Series Non Stationary \\
\hline DOPEN & $-3.134 * *$ & $-3.782 * *$ & $-3.089 *$ & Series Stationary I(1) \\
\hline DTT & -3.104 & -1.522 & $1.637 * * *$ & Series Stationary I(1) \\
\hline
\end{tabular}

Table 2. ADF Unit Root Test at First level\#

\# Figures in parenthesis are optimal lags based on SIC criteria

$*, * *$ and $* * *$ reflect the significance level at $1 \%, 5 \%$ and $10 \%$ respectively.

\section{Co-Integration Results}

\begin{tabular}{|c|c|c|c|c|c|}
\hline \multicolumn{6}{|c|}{ Unrestricted Co-integration Rank } \\
\hline Hypothesized & Trace & 0.05 & Max-Eigen & 0.05 & \\
\hline No. of CE(s) & Statistic & Critical Value & Statistic & Critical Value & Prob.** \\
\hline None * & 338.8023 & 159.5297 & 102.0873 & 52.36261 & 0.0000 \\
\hline At most $1 *$ & 236.7150 & 125.6154 & 90.56407 & 46.23142 & 0.0000 \\
\hline At most $2 *$ & 146.1510 & 95.75366 & 50.99606 & 40.07757 & 0.0000 \\
\hline At most $3 *$ & 95.15491 & 69.81889 & 39.23916 & 33.87687 & 0.0001 \\
\hline At most $4 *$ & 55.91575 & 47.85613 & 33.21686 & 27.58434 & 0.0073 \\
\hline At most 5 & 22.69889 & 29.79707 & 10.70513 & 21.13162 & 0.2612 \\
\hline At most 6 & 11.99376 & 15.49471 & 9.703327 & 14.26460 & 0.1572 \\
\hline At most 7 & 2.290437 & 3.841466 & 2.290437 & 3.841466 & 0.1302 \\
\hline
\end{tabular}

Table 3. Johansen test, Co-integration Rank Test (trace)

Series: REER TT OPEN OIL NCF TR LQ GC

Lags interval (in first differences): 1 to 4

* denotes rejection of the hypothesis at the 0.05 level

**MacKinnon-Haug-Michelis (1999) p-values

\begin{tabular}{|c|c|c|c|c|c|c|c|c|c|}
\hline Variables & REER(-1) & OIL(-1) & GC(-1) & LQ(-1) & TR(-1) & NCF(-1) & OPEN(-1) & TT(-1) & C \\
\hline Vector Co-efficient & 1.000 & 7.307 & 100.092 & 16.423 & -14985.6 & -153.376 & -46.458 & -43.537 & 814.17 \\
\hline Standard errors & & (3.478) & (60.897) & (3.696) & (1893.02) & $(19.290)$ & $(9.015)$ & $(6.224)$ & \\
\hline t-statistics & & {$[2.10]$} & [ 1.64$]$ & [ 4.44$]$ & {$[-7.92]$} & {$[-7.95]$} & {$[-5.15]$} & {$[-6.99]$} & \\
\hline
\end{tabular}

Table 4. Vector Error Correction Estimates (Long Run)

Standard errors in ( ) \& t-statistics in [ ]

After checking the stationary of the time series variables, and before estimating the Algerian DZD, I first identify the maximum number of legs to use. Therefore, I use Akaike Information Criterion (AIC) and Schwarz Criteria (SC) to 
choose the optimal lag length. According to AIC criterion I take 4 lags. The results of the unrestricted Johansen cointegration test applied to all the variables are presented in Table 3. Note that the regression is conducted on first difference of all the series. The standard statistics used in the interpretation of the test are the eigenvalue and the trace statistic at given level of significance.

From the results showed in the Table 3 there exist five cointegration equations where the maximum eigenvalue and the trace statistic are both greater than their critical values.
According to Cerra and Sexena (2002) and Mathisen (2003) approach, I use the first co-integration vector to show the long run relationship between Algerian DZD real effective exchange rate and its fundamentals.

Next step I do the co-integration regression, the Table 4 shows the long run behavioral co-integration vector coefficient of the Algerian Dinar (DZD) real effective exchange rate, the long run equilibrium equation can be written as follows:

$$
R E E R_{t}=814.17+7.307 O_{O I L}+100.092 G C_{t}+16,423 L Q_{t}-14985.6 T R_{t}-153.376 N C F_{t}-46.458 O P E N_{t}-43.537 T T_{t}
$$

This results can be discerned from the results that all coefficients are enough strong and statistically significant. The overall performance of the regression is smooth; there is only one coefficient, the total reserve including gold (TR) has a negative impact by -14985.6 on the real effective exchange rate, which has an opposite sign to the one we expect at the beginning in equation (2). I can refer this to the accumulation that is associated with domestic currency depreciation in the medium run but eventually an appreciation in the long run. Moreover, the total reserve including gold to GDP is significant which mean can be interpreted by less central bank intervention.

The coefficient of oil price (OIL) has a correct sign and is statistically significant, a unit change in oil price is associated with real effective exchange rate appreciation by up 7,307 units. And since Algeria is hydrocarbon exports country, an increase in the oil price will lead to an increase in capital inflows. Similarly, The government expenditure (GC) coefficient is positive, which leads to DZD real effective exchange rate appreciation if the government consumption increase. This explains that the proportion of government expenditure on the non-tradable goods is greater than proportion of tradable ones. The liquidity to GDP (LQ) coefficient is positive and significant at 1 percent level. A change by one unit up in liquidity to GDP, will impact an increasing in the value of DZD real effective exchange rate by 16.423. That means the increase in the price of liquidity ratio will lead to increase in prices and an appreciation of real effective exchange rate (decrease in the value of DZD). All of Net Capital Flows (NCF), Trade Openness (OPEN) and Terms Of Trade (TT) have negative impact on real effective exchange rate and all are significant at 1 percent level. Which means any increase in one of three proxies will lead in real effective exchange rate depreciation (rising in the DZD value). However, to estimate the relationship between the real exchange rate and its determinants in the short run, I run the regression of the vector error correction model VECM, the Table 5 reports the empirical results for VEC model.

Table 5. Vector Error correction Estimation, (First different, short run)

\begin{tabular}{|c|c|c|c|c|c|c|c|}
\hline Variables & D(OIL) & D(GC) & $\mathbf{D}(\mathbf{L Q})$ & D(TR) & D(NCF) & D(OPEN) & D(TT) \\
\hline Adjustment Co-efficient & -0.00133 & 0.000336 & 0.000397 & 0.000145 & -0.01206 & -0.00037 & -0.00304 \\
\hline standard errors & $(0.00224)$ & $(0.00011)$ & $(0.00052)$ & $(0.00043)$ & $(0.00428)$ & $(0.0006)$ & $(0.00181)$ \\
\hline t-statistics & {$[-0.591]$} & {$[2.937]$} & {$[0.765]$} & [3.394] & {$[-2.819]$} & {$[-0.622]$} & {$[-1.683]$} \\
\hline
\end{tabular}

Standard errors in ( ) \& t-statistics in [ ]

I can classify the coefficients as follow:

The proxies Oil price (OIL), Liquidity to GDP (LQ) and Openness of Trade are not statistically significant in the short run.

However the government expenditure (GC), total reserve including gold (TR), net capital flow (NCF) and the terms of trade are all most statistically significant at 1 percent level, where GC and TR have positive impact on DZD teal effective exchange rate. On contrary, NCF and TT have a negative effect on DZD REER in the short run, which leads depreciation in the value or REER.

\section{Real Effective Exchange Rate Misalignment}

In this part, I present how the estimated long run relationship between the Algerian dinar real effective exchange rate and its determinants is decomposed into permanent and transitory or cyclical components. This involves applying the long run values of the VECM coefficients to the actual values of the macroeconomic fundamentals in a given period to obtain a consistent long run equilibrium value for REER. The Figure 1 and Figure 2 show the graph of BEER and its Residual series.

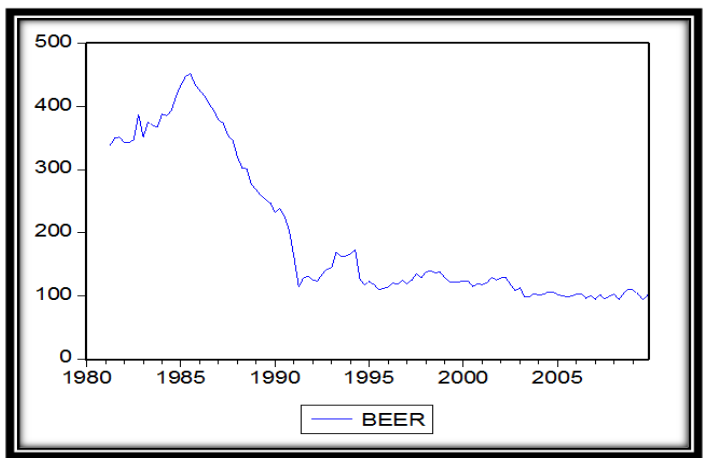

Figure 1. The Behavioral Equilibrium Exchange Rate 


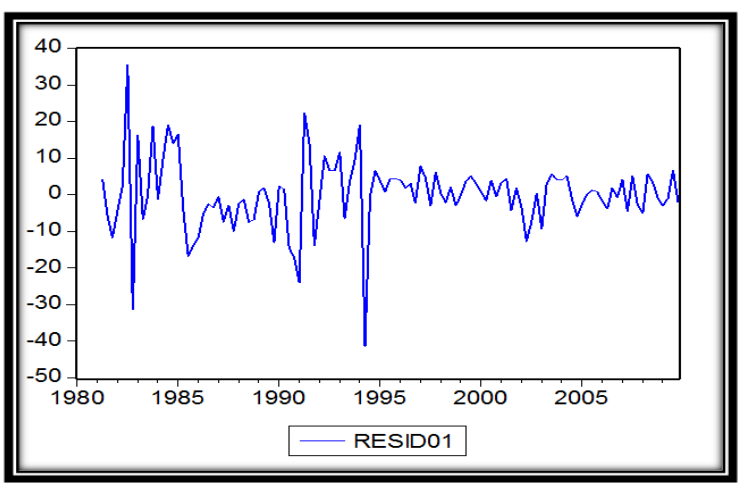

Figure 2. Behavioral equilibrium exchange rate Residuals

On the other hand, I smooth out the behavioral equilibrium to yield the permanent equilibrium exchange rate (PEER), by using the Hodrick-Prescott filter. The later was firstly introduced by Hodrick and Pescott (1997) who had applied this method to estimate the long run trend or permanent part of a time series, and the framework can be written as the following form:

$$
y_{t}=\tau_{t}+c_{t}, t=1,2, \ldots, T .
$$

Where:

$\tau_{\mathrm{t}}$ : is trend component.

$\mathrm{C}_{\mathrm{t}}$ : is cyclical component.

The Figure 3 and Figure 4 present the graph of the PEER, which is less vitality than the BEER and cyclical series obtained using HP decomposition

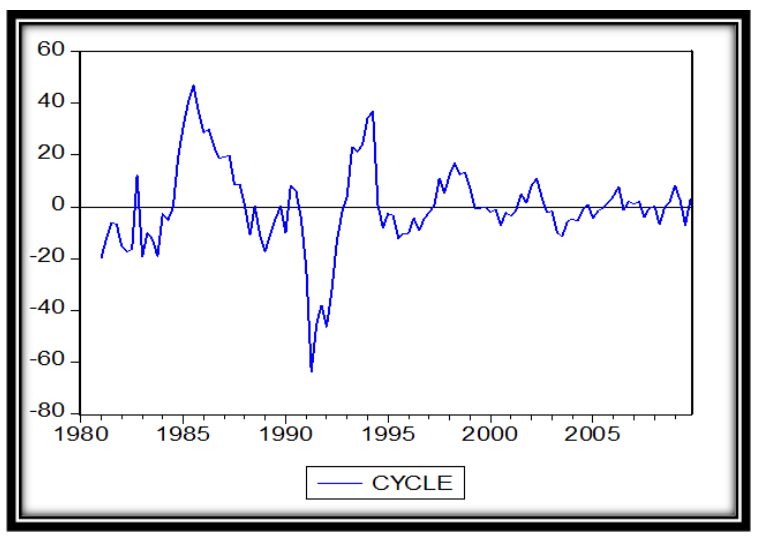

Figure 3. Permanent Equilibrium Exchange Rate

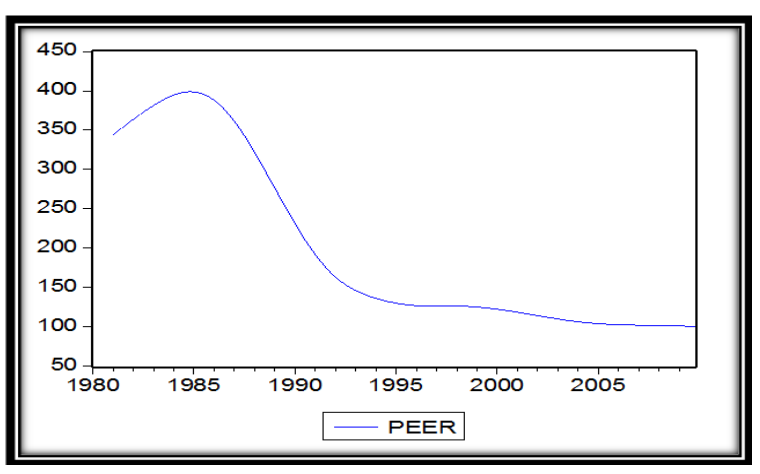

Figure 4. Cyclical shock of exchange rate

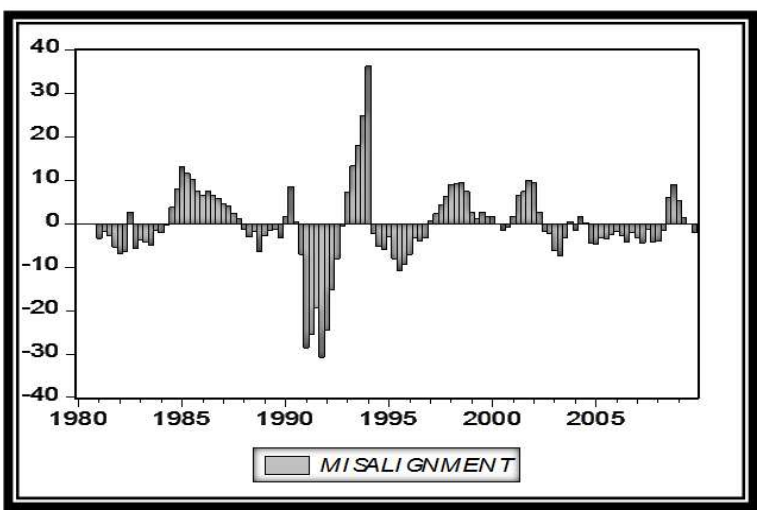

Figure 5. Exchange rate misalignment

Finally, and after I obtained the REER (Real Effective Exchange Rate), BEER (Behavioral Equilibrium Exchange Rate) and PEER (Permanent Equilibrium Exchange Rate), now I put them in one figure, Figure 5

Meanwhile the degree of misalignment computed based on the above formula:

$$
\text { Misalignment }=[(\text { REER-PEER }) / \text { PEER }]^{*} 100^{15}
$$

I can see that if misalignment greater than zero, it means that the REER is over-valuated. If the misalignment greater than zero, it means that the REER is overvalued. The Figure 6 shows the REER misalignment.

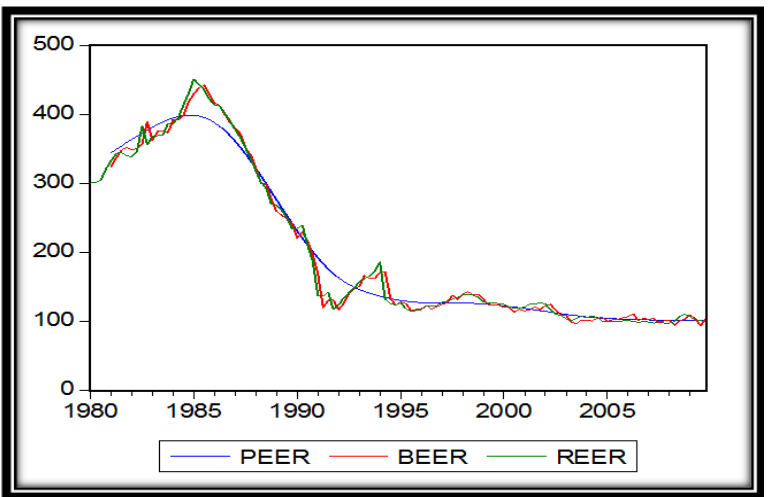

Figure 6. Real Effective Exchange rate Misalignment

The results showed that the variation of Algerian misalignment was very large, between -30,712\%(1991Q4) and $36.321 \%$ (1994Q1). In the whole period the variation of the Algerian dinar DZD real effective exchange rate absolute value is varying less than $12 \%$, which is referred that the DZD REER is quite near to its equilibrium, except in the period 1990Q3 to 1994Q3. In the beginning of the later period the DZD REER was arrived at the lowest value in the whole empirical period. That was because the relative stability of the nominal rate did not correspond to the economic fundamentals, which lets the government fiscal to apply monitory policies, thus resulted a high inflation.

15 - See Shehu Usman Rano, Aliyu, “ Real exchange rate misalignment: an application of behavioral equilibrium exchange rate to Nigeria", (2008), Munich Personal RePEc archive 
Therefore, it causes in high appreciation in the Algerian dinar DZD.

On contrary, in 1994 the authorities has applied an adjustment program to correct the real appreciation of the Algerian dinar DZD, which implies the Algerian Dinar DZD real effective exchange rate to over-valuate ${ }^{16}$.

\section{Conclusion}

I used Johansen Co-integration approach to estimate Behavioral equilibrium exchange rate for Algerian Dinar DZD based on various macroeconomic fundamentals. The main explanatory variables found to be oil price (OIL), Government consumption (GC), liquidity ratio (LQ), Total reserve including gold (TR), net capital flows (NCF), capital flows (CF), trade openness (OPEN) and terms of trade (TT). The results of the reduce relationship between the Algerian dinar DZD real effective exchange rate and the degree of misalignment raged between $(-28.532 \%)$ and (36.321\%), as far as the behavioral of exchange rate misalignment over the period under view is concerned.

This research also identified four Algerian Dinar's DZD under-valuate episodes (1981Q1-1984Q2 period, 1988Q11992Q4 period and 1994Q2-1996Q4 period and 2002Q32008Q2 period) and three episodes of over-valuated ones (1984Q3-1987Q4 period, 1993Q1-1994Q1 period and 1997Q1-2002Q2 period).

After finishing the analys of this research, I could notice that the impact of applying the monetary policy of Algerian DZD was quite effectively to realize the authority objectivities of certain program .

Finally this results yield following important policy implication for Algeria. Firstly, the BEER is not fixed and subject to variability due to change in economic fundamentals, hence requires changes in BEER and actual REER accordingly. Secondly, the continued prudent monetary policy is effectively on the Algerian Dinar DZD's real effective exchange rate. Last and not least the actual Algerian DZD's real effective exchange rate appreciation due to higher price differentials relative to behavioral equilibrium exchange rate would lead to exchange rate misalignment.

\section{References}

[1] Azali, M., M.S. Habibullah and A.Z. Baharumshah (2001) Does PPP hold between Asian and The Japanese Economies? Evidence Using Panel Unit Root and Panel Cointegration, Japan and the World Economy, 13, 35-50.

[2] Baffes, J., I. Elbadawi, and S. O'Connell. (1999) "SingleEquation Estimation of the Equilibrium Real Exchange Rate." World Bank, Policy Research Department, Washington, DC.

[3] Baharumshah, A.Z. and M. Ariff (1997) Purchasing Power Parity in South East Asian Countries: A Co-integration Approach, Asian Economic Journal, 11, 141-154.

\footnotetext{
16 - "Guide to investing in Algeria", KPMG Algerie SPA, (2012), 27.
}

[4] Bahmani-Oskooee, M., (1993) Purchasing Power Parity Based on Effective Exchange Rate and Co-integration; 25 LDCs Experience with its Absolute Formulation, World Development, 21, 1023-31.

[5] Bahmani-Oskooee, M., (1993) Purchasing Power Parity Based on Effective Exchange Rate and Co-integration; 25 LDCs Experience with its Absolute Formulation, World Development, 21, 1023-31.

[6] Balassa, B. (1964) The Purchasing Power Parity Doctrine: A Reappraisal. Journal of Political

[7] Bassem Kamar, "The appropriate monetary policy coordination for the GCC monetary union", (2006), International university of Nice-Sophia Antipolis, pp. 1-24

[8] Bassem Kamar, "Defacto exchange rate policies in the mena region: toward deeper co-operation", (2004), International university of Monaco, pp. 1-19

[9] Chinn, M. D. (2000) The Usual Suspects: Productivity and Demand Shocks and Asian-Pacific Exchange Rates. Review of International Economics 8:1, 20-43.

[10] Chishti Salim and Hasan M. Aynul, (1995), "What Determines the Behavior of Real Exchange Rate in Pakistan", The Pakistan Development Review, Vol.34 pp.1015-1029

[11] Choudhry, T. (2005) Asian Currency Crisis and the Generalized PPP: Evidence from the Far East, Asian Economic Journal, 19(2), 137-157.

[12] Co-integration Techniques", Applied Economics, 20(10), pp. $1369-81$.

[13] Dedi Cahyono, (2008), "Determinants of equilibrium real exchange rate and its misalignment in indonisia", istitue of social studies, pp. 13- 55.

[14] Denes Kucsra, " equilibrium exchange rate", Comenius university Bratislava, (2007), pp. 1-48.

[15] Devarajan, R. (1997) Real Exchange Rate Misalignment in the CFA Zone, Journal of African Economies, Oxford, Vol. 6, No. 1, pp. $35-53$.

[16] Dufrenot, G., and E. Yehoue, (2005) "Real Exchange Rate Misalignment: A Panel Co-integration and Common Factor Analysis," IMF Working Paper 05/164 (Washington:International Monetary Fund).

[17] Economy 72, 584-596.

[18] Edwards, S., (1989) Real Exchange Rates, Devaluation, and Adjustment: Exchange Rate Policy in Developing Countries (Cambridge, Massachusetts: MIT Press).

[19] Elbadawi, I. and R. Soto. (1997) "Real Exchange Rate and Macroeconomic Adjustment in Sub- Saharan Africa and Other Developing Countries.” in Elbadawi, I. and R. Soto, (eds.), Foreign Exchange Market and Exchange Rate Policies in SubSaharan Africa, Supplementary Edition of the Journal of African Economies.

[20] Elbadawi, I., (1994) "Estimating Long Run Real Exchange Rates," in Estimating Equilibrium Exchange Rates, ed by J. Williamson (Washington: Institute for International Economics).

[21] Engle, Robert F. and C. W. J. Granger (1987). "Co-integration and Error Correction: Representation, Estimation, and Testing," Econometrica, 55, 251-276. 
[22] Exchange Rate (BEER) to Botswana," IMF Working Paper WP/06/140 (Washington: International Monetary Fund).

[23] Ghura, D. and T. J. Greenes (1993) "The Rea Exchange Rate and Macroeconomic Performance in Sub-Saharan Africa," Journal of Development Economics. 42: 155 - 174.

[24] "Guide to investing in Algeria", KPMG Algerie SPA, (2012), 27

[25] Iimi, A., (2006) "Exchange Rate Misalignment: An Application of the Behavioral Equilibrium

[26] Iossifov, P. and E. Loukoianova (2007) Estimation of a Behavioral Equilibrium Exchange Rate Model for Ghana, IMF Working Paper WP/07/155 (Washington: International Monetary Fund).

[27] Johansen S. and K. Juselius, (1990) "Maximum Likelihood Estimation and Inference on Co-integration, with Application to the Demand for Money", Oxford Bulletin of Economics and Statistics, Vol. 52 (may), pp. 169-210.

[28] Johansen, S., (1988) "Statistical Analysis of Co-integration Vectors", Journal of Economic Dynamics and Control, Vol. 2 (June-September), pp. 231-54.

[29] Likka Korhonen and Tuuli Juurikkala, "Equilibrium Exchange rates in oil-dependent countries",(2007), Bank Of Finland Institute for Economies in Transition (BOFIT), pp. 15 .

[30] MacDonald, R., and J. Nagayasu, (1998) "On the Japanese Yen-U.S. Dollar Exchange Rate: A 31 Structural Econometric Model Based on Real Interest Differentials," Journal of the Japanese and International Economies, Vol. 12 (March), pp. 75-102.

[31] Maesofernandez, F.C. Osbat, B. Schnatz (2001) Determinants of the Euro Real Effective Exchange Rate: A BEER/PEER approach European Central Bank (ECB) Working Paper Series, No. 85.

[32] McNown, R. and M. Wallace, (1989) National Price Level, Purchasing Power Parity, and Co-integration: A test of Four High Inflation Economies, Journal of International Money and Finance, 8, 533-45.
[33] Mollick, A.V., (1999) The Real Exchange Rate in Brazil: Mean Reversion or Random Walk inthe Long run? International Review of Economics and Finance, 8, 115-126.

[34] Moosa, I. A., and R. H. Bhatti ( 1996) Does Purchasing Power Parity Hold between Japan and Other Asian Countries. Journal of International Economic Studies 10, 85-94.

[35] Phillips, P.C.B. and P. Perron (1988). "Testing for a Unit Root in Time Series Regression,” Biometrika, 75, 335-346.

[36] Rogoff, Kenneth, 1996, "The Purchasing Power Parity Puzzle", Journal of Economic Literature, Vol. 34, pp. 647-68.

[37] Sarantis, N., and C. Stewart (1993) Sea-Sanality, Cointegration and the Long-run Purchasing Power Parity: Evidence for Sterling Exchange Rates. Applied Economics 25, 243-250.

[38] Serven L., and A. Solimano, (1991), "An empirical Macroeconomic model for Policy Design: The case of Chile", Research Policy Series No. 709, Washington DC, World Bank.

[39] Shehu Usman Rano, Aliyu, " Real exchange rate misalignment: an application of behavioral equilibrium exchange rate to Nigeria", (2008), Munich Personal RePEc archive, pp. 1-25.

[40] Taline Koranchelian, "The equilibrium real exchange rate in commodity exporting country: Algeria's Experince", (2005), IMF working paper, pp. 1-17.

[41] Taylor, M. P. “An Empirical Examination of Long run Purchasing Power Parity using co-integration thechnique",(1988), applied economics, pp. 1369-81.

[42] Williamson "Estimates of FEERs", in J. Williamson: Estimating Equilibrium Exchange Rates, (1994), Washington, D.C., $177-244$.

[43] Yotopoulos A. Pan and Sawada Yasuyuki, "Exchange Rate Misalignment: A New Test of Lung-Run PPP Based on CrossCountry Data", (2005), CIRJE Discussion Paper, February.

[44] Zulfiqar Hyder and Adil Mahboub, "Equilibrium real effective exchange rate and exchange rate misalignment in Pakistan", (2005), SBP electronic board, pp. 1-26.

[45] http://data.worldbank.org 